\title{
Studi Perbandingan Metode Wavelet Dalam Speech Recognition Pada Sistem Akses Personel
}

\author{
Ariyawan Sunardi ${ }^{1}$, Rezky Mahardika ${ }^{2}$, Heri Suherkiman ${ }^{3)}$, Sunarko $^{4}$, Kawkab Mustofa ${ }^{5}$, \\ Hanapi Ali $^{6)}$ Dan Sri Sundari Retnoasih ${ }^{7)}$ \\ ${ }^{1-7)}$ Pusat Reaktor Serba Guna (PRSG), BATAN, Indonesia \\ email: ${ }^{1)}$ ariyawan@batan.go.id
}

\begin{abstract}
Abstrak- Penelitian tentang speech recognition terus berkembang terkait identifikasi personel. Pada penelitian ini, kami melakukan studi perbandingan metode wavelet dalam speech recognition. Pada penelitian ini teknologi speech recognition berbasis wavelett dan neuro fuzzy. Beberapa parameter yang digunakan dalam penelitian ini adalah sampel suara dengan frekuensi sampling $8000 \mathrm{~Hz}$ dan 8 bit per sampel dengan filter wavelet High Pass Filter (HPF). Level dekomposisi menggunakan wavelet daubechies, symlet dan coiflet. Nilai thereshold filter wavelet identifikasi personel $57,72 \%$, False Rejection Rate (FRR) 40\% dan Running time 1,97 detik. Untuk nilai thereshold identifikasi personel $100 \%$, False Rejection Rate (FRR) 0\% dan Running time 5,43 detik didapatkan pada level dekomposisi 5 pada wavelet db1. Identifikasi tipe wavelet yang terbaik adalah coiflet, symlet dan daubechies karena coif2 level 2 memberikan identifikasi $60,00 \%$, FRR $40,00 \%$ dan Running time 1,97 detik (Times New Roman, 9 pt).
\end{abstract}

Kata Kunci : Speech Recognition, perbandingan wavelet, coiflet, symlet, daubechies.

\section{Pendahuluan}

Biometrik, termasuk di dalamnya speech recognition, secara umum digunakan untuk identifikasi dan verifikasi. Identifikasi ialah mengenali identitas seseorang, dilakukan perbandingan kecocokan antara data biometrik seseorang dalam database berisi rekaman karakter seseorang. Sedangkan verifikasi adalah menentukan apakah seseorang sesuai dengan apa yang dikatakan terhadap dirinya[1].

Speech recognition merupakan suatu proses yang dilakukan komputer untuk mengenali kata yang diucapkan oleh seseorang tanpa mempedulikan identitas orang terkait [2]. Suara merupakan salah satu sistem biometrik yang paling terkenal dan mudah dalam penerapan hardware. Suara manusia tidak dapat dikenali begitu saja ketika dimasukkan ke dalam komputer. Sinyal suara manusia yang diterima melalui mikrofon berupa sinyal analog sehingga harus diubah menjadi sinyal digital.

Sinyal digital yang didapat akan diolah untuk mengenalnya, diantaranya adalah pre prosesing, ekstrasi fitur dan pengenalan pola. Pre prosesing dilakukan untuk mendapatkan ciri dasar dari sinyal suara. Ekstraksi fitur digunakan transformasi terhadap suara untuk mengubah domain waktu pada suara menjadi domain frekuensi. Transformasi merupakan proses pengubahan data atau sinyal ke dalam bentuk lain agar lebih mudah dianalisis, seperti transformasi fourier yang mengubah sinyal ke dalam beberapa gelombang sinus atau cosines dengan frekuensi yang berbeda, sedangkan transformasi wavelet

mengubah sinyal ke dalam berbagai bentuk wavelet (mother wavelet) dengan berbagai pergeseran dan penyekalaan (Kadir, 1998)[3] .

Wavelet telah banyak diaplikasikan dalam bidang penelitian terkait pemrosesan sinyal. Misalnya pada pengenalan suara otomatis, wavelet digunakan dalam ekstraksi ciri suatu sinyal suara. Selain itu, wavelet mengungguli FFT karena mampu untuk memetakan sinyal ke dalam domain frekuensi - waktu secara bersamaan sehingga dalam prosesnya tidak ada data sinyal yang hilang (Rashmi 2014; Anusuya \& Katti 2011). Meskipun demikian, tidak semua fungsi wavelet dapat diaplikasikan pada sinyal suara karena wavelet memiliki banyak family. Namun tidak semua family wavelet tersebut dapat diaplikasikan pada objek sinyal yg sama pada pengenalan suara sehingga dalam aplikasinya penggunaan wavelet masih terkesan trial dan error [4]. Oleh karena itu, pada penelitian Syahroni dkk (2017) telah dilakukan penentuan tingkat kemiripan fungsi basis wavelet terhadap sinyal di mana wavelet akan diaplikasikan. Dengan demikian, kemampuan sistem pengenalan suara dimungkinkan akan meningkat. Dalam hal ini, salah satu metode yang dapat digunakan untuk menentukan tingkat kemiripan antara sinyal suara dengan fungsi basis wavelet adalah dengan menghitung nilai korelasi antara keduanya. Hasil penelitian menunjukkan bahwa untuk suara vocal bahasa Indonesia a, i, u, e, è, o, dan ò dengan panjang segmentasi 2048 data diperoleh db45 merupakan fungsi basis wavelet terbaik. Adapun berdasarkan jenis kelamin maka fungsi basis wavelet $\mathrm{db} 44$ dan fungsi basis wavelet db45 secara berturut-turut merupakan fungsi terbaik untuk suara vokal pria dan wanita.

Pada penelitian Yohanes TDS dkk (2002) telah dilakukan aplikasi neuro fuzzy untuk pengenalan kata. Sistem ini telah diuji dengan membandingkan struktur neuro-fuzzy dengan neural network. Hasil yang dicapai memperlihatkan bahwa sistem neuro-fuzzy memberikan hasil yang lebih baik dibandingkan dengan system neural network. Waktu pembelajaran sistem neuro-fuzzy lebih cepat dibandingkan dengan neural network. Untuk 270 sampel suara, sistem neuro-fuzzy menyelesaikannya dengan 160.000 iterasi sedangkan neural network membutuhkan 500.000 iterasi. Nilai persentase kebenaran tertinggi dari sistem Neuro-fuzzy mencapai 96,36\% sedangkan sistem neural network mencapai 62,86\% [5].

Penelitian ini dilakukan penerapan speech recognition yang bertujuan untuk identifikasi personel berdasarkan database 
suara personel. Transformasi wavelet digunakan sebagai ekstraksi fitur dan neuro fuzzy sebagai metode klasifikasi. Pada kasus ini dilakukan perbandingan 3 (tiga) metode wavelet yaitu Daubechies, Symlet dan Coiflet dalam kecepatan identifikasi personel. Penelitian ini dibatasi pada sistem identifikasi personel dan adanya notifikasi untuk personel yang tidak memiliki akses .

\section{Metodologi Penelitian}

Pada tahap awal adalah proses akuisisi data suara dimana terdapat sejumlah 22 file suara sebagai data masukan. Tahap berikutnya dalah proses pengolahan citra. Proses ini dilakukan untuk memperbaiki kualitas file suara dan segmentasi suara. Teknik yang dilakukan pada tahap ini adalah thresholding. Tahap berikutnya adalah tahap pengenalan file suara. Tahap ini terdiri dari ekstraksi ciri dan identifikasi/klasifikasi personel. Tahap ekstraksi ciri dilakukan dengan metode Discrete Wavelet Transform (DWT) dengan pilihan empat jenis wavelet yaitu wavelet daubechies, wavelet coiflet dan wavelet symflet. Untuk tahap identifikasi/klasifikasi dilakukan dangan Adaptive Neuro Fuzzy Systems (ANFIS).

\subsection{Alat dan Bahan}

Perangkat atau peralatan yang dibutuhkan dalam penelitian ini antara lain:

1. Microphone

2. Head Speaker

3. Laptop dengan spesifikasi minimum Processor Intel Pentium 4, memory 1GB, Harddisk 60 GB.

\subsection{Transformasi Wavelet}

Wavelet merupakan alat analisis yang biasa digunakan untuk menyajikan data atau fungsi atau operator ke dalam komponen-komponen frekuensi yang berlainan, dan kemudian mengkaji setiap komponen dengan suatu resolusi yang sesuai dengan skalanya [6]. Selain itu wavelet merupakan gelombang mini (small wave) yang mempunyai kemampuan mengelompokkan energi citra dan terkonsentrasi pada sekelompok kecil koefisien, sedangkan kelompok koefisien lainnya hanya mengan-dung sedikit energi yang dapat dihilangkan tanpa mengurangi nilai informasinya. Keluarga fungsi yang dihasilkan oleh wavelet basis $\psi(\mathrm{x})$ disebut mother wavelet. Dua operasi utama yang mendasari wavelet adalah [3]:

1) penggeseran, misalnya $\psi(\mathrm{x}-1), \psi(\mathrm{x}-2), \psi(\mathrm{x}-\mathrm{b})$, dan

2) penyekalaan, misalnya $\psi(2 \mathrm{x}), \psi(4 \mathrm{x})$ dan $\psi(2 \mathrm{j} \mathrm{x})$.

Kombinasi kedua operasi inilah menghasilkan basis wavelet. Secara umum, keluarga wavelet sering dinyatakan dengan persamaan:

$$
\Psi_{\mathrm{a}, \mathrm{b}}^{(x)}=\frac{1}{\sqrt{ }|a|} \Psi\left(\frac{x-b}{a}\right) .
$$

Beberapa contoh basis wavelet adalah Haar, Daubechies, Symlets, Coiflets, BiorSplines, ReverseBior, Meyer, DMeyer, Gaussian, Mexican_hat, Morlet, Complex Gaussian, Shannon, Frequency B-Spline, Complex Morlet, Riyad dan lain sebagainya [7]. Alasan transformasi wavelet menjadi penting dalam berbagai bidang karena sifat-sifat berikut [8]:
1) Waktu kompleksitasnya bersifat linear. Transformasi wavelet dapat dilakukan dengan sempurna dengan waktu yang bersifat linear.

2) Koefisien-koefisien wavelet yang terpilih bersifat jarang. Secara praktis, koefisien-koefisien wavelet kebanyakan bernilai kecil atau nol. Kondisi ini sangat memberikan keuntungan terutama dalam bidang kompresi atau pemampatan data.

3) Wavelet dapat beradaptasi pada berbagai jenis fungsi, seperti fungsi tidak kontinyu, dan fungsi yang didefinisikan pada domain yang dibatasi.

Basis wavelet yang digunakan dalam proses ekstraksi fitur suara atau sinyal 2-dimensi adalah sebagai berikut [3]:

1) Daubechies Ingrid, Daubechies merupakan salah satu dari bintang paling cemerlang dalam bidang penelitian wavelet. Panjang tapis untuk semua keluarga daubechies adalah $\mathrm{dbN}=2 \mathrm{~N}$, dan lebarnya $2 \mathrm{~N}-1$. Misalnya db2, panjang tapisnya adalah 4 . Tapis lolosbawah $(\varphi)$ db2 yang telah melalui normalisasi = [ $\left.\begin{array}{llll}0.1294 & 0.2241 & 0.8365 & 0.4830\end{array}\right]$, dan tapis lolos-tinggi $(\psi)=\left[\begin{array}{llll}-0.4830 & 0.8365 & -0.2241 & 0.1294\end{array}\right]$.

2) Coiflets dibangun oleh daubechies atas permintaan coifman [3]. Panjang tapis untuk wavelet coiflet adalah $6 \mathrm{~N}$, dan lebarnya $6 \mathrm{~N}-1$. Misalnya coif1, maka panjang tapisnya adalah 6. Tapis lolos-bawah $(\varphi)$ coifl yang

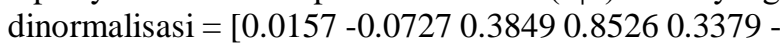
0.0727], dan tapis lolos-tingginya $(\psi)=[0.0727$ 0.3379 -0.8526 $0.3849 .0727-0.0157]$.

3) Symlets, Wavelet Symlet memiliki nama pendek sym, untuk orde N dituliskan dengan SymN. Wavelet Symlet memiliki orde $\mathrm{N}=2, \ldots, 45$. Panjang tapis untuk Wavelet Symlet adalah $2 \mathrm{~N}$.

\subsection{Adaptive Neuro Fuzzy System (ANFIS)}

Neuro-fuzzy adalah gabungan dari dua sistem yaitu sistem logika fuzzy dan jaringan syaraf tiruan. Sistem neurofuzzy berdasar pada sistem inferensi fuzzy yang dilatih menggunakan algoritma pembelajaran yang diturunkan dari sistem jaringan syaraf tiruan. Dengan demikian, sistem neuro-fuzzy memiliki semua kelebihan yang dimiliki oleh sistem inferensi fuzzy dan sistem jaringan syaraf tiruan. Dari kemampuannya untuk belajar maka sistem neuro-fuzzy sering disebut sebagai ANFIS (Adaptive Neuro Fuzzy Inference Systems) [9]. Sistem inferensi fuzzy yang digunakan adalah sistem fuzzy model Takagi, Sugeno and Kang (TSK) orde satu dengan pertimbangan kesederhanaan serta kemudahan komputasi. Pertimbangan ini penting karena sistem tersebut akan melalui suatu proses belajar yang mempunyai beban komputasi besar.

Pada sistem inferensi fuzzy TSK orde satu dengan dua masukan, aturan yang digunakan adalah

Aturan 1: If $x$ is $A_{1}$ and $y$ is $B_{1}$ then $f_{1}=p_{1} x+q_{1} y+r_{1}$ Aturan 2: If $x$ is $A_{2}$ and $y$ is $B_{2}$ then $f_{2}=p_{2} x+q_{2} y+r_{2}$. Sistem neuro-fuzzy yang ekivalen dengan sistem inferensi fuzzy di atas mempunyai struktur jaringan dengan lima lapisan. Tiap lapisan mempunyai fungsi yang berbeda dan terdiri atas beberapa simpul. Lapisan ANFIS dapat dilihat pada gambar 1 . 


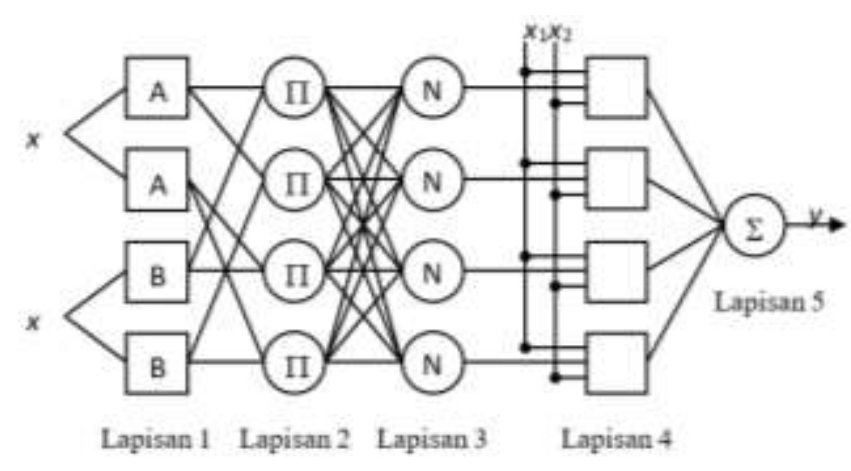

Gambar 1. Struktur neuro-fuzzy.

\subsection{Diagram Penelitian,}

Sistem identifikasi personel menggunakan speech recognition yang dirancang dalam penelitian ini dapat dilihat pada gambar 2 .

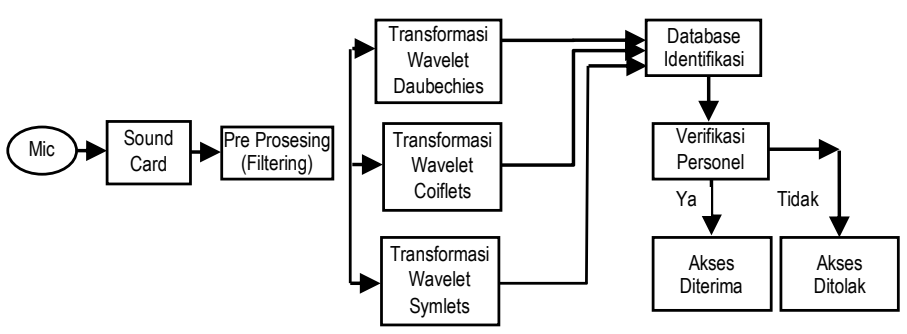

Gambar 2. Diagram Blok Sistem Identifikasi Personel

Pada gambar 1 dilihat proses kerja sebagai berikut :

a. Transducer dalam hal ini mikrofon mengubah tekanan udara (yang kita dengar sebagai suara) ke dalam tegangan elektrik yang dapat dimengerti oleh perangkat elektronik.

b. Tegangan elektrik diproses menjadi sinyal digital oleh sound card. Sound card akan mengubah gelombang suara (bisa dari mikrofon atau stereo set) menjadi data digital, dan ketika suara itu dimainkan kembali, sound card akan mengubah data digital menjadi suara yang kita dengar (melalui speaker), dalam hal ini gelombang analog.

c. Preprosesing filter pada sinyal input untuk menghilangkan sinyal DC (nol). Dalam tahap ini dilakukan perbaikan kualitas suara yang akan diolah. Teknik yang dilakukan dalam tahap ini adalah thresholding [10]

d. Dekomposisi merupakan sebuah metode untuk ekstraksi ciri dari sinyal suara [10]. Transformasi wavelet akan melakukan dekomposisi untuk mengekstraksi informasi yang ada didalam sinyal suara, dengan membagi atau memecah sinyal tersebut ke dalam band-band frekuensi. Gambar 5 menunjukkan sinyal suara yang dibagi ke dalam 4 (empat) band informasi yang masing-masing akan dihitung nilai Entropi dari setiap bandnya. Nilai dekomposisi divariasi untuk menunjukkan tingkat pengenalan personel.

e. Hasil ekstrasi ciri dari dekomposisi wavelet akan menjadi input untuk pembuatan database personel menggunakan Adaptive Neuro-fuzzy Inference System (ANFIS).
Identifikasi personel akan dididapatkan sebagai output dari ANFIS.

f. Setelah diperoleh database personel, akan diuji dengan verifikasi sampel suara untuk mengetahui akses diterima atau ditolak.

\section{User Authorization}

Sistem User Authorization dibuat untuk jaminan keamanan dan keselamatan personel dan instalasi.

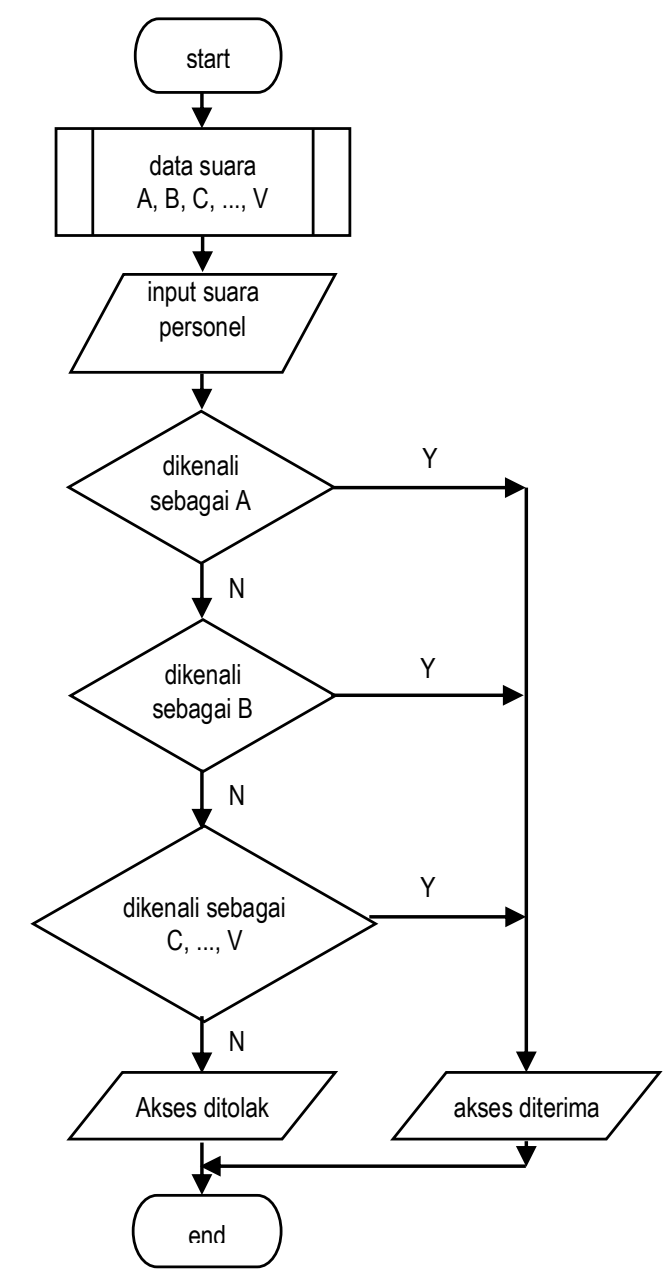

Gambar 3. Flowchart Sistem User authorization

\section{Hasil dan Pembahasan}

Pengujian ANFIS untuk identifikasi personel yang ditelah dirancang, dilakukan dengan memperhatikan masukan dan keluaran.

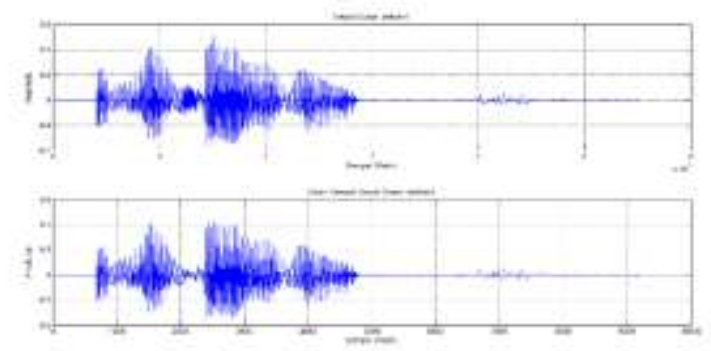

Gambar 4. Sinyal masukan dari suara 
Untuk sinyal masukan yang diperlukan adalah sinyal suara dengan frekeunsi sampling $8000 \mathrm{~Hz}$, dan sampel per bit 8 bit. Dasar pertimbangan menggunakan frekuensi sampling $8000 \mathrm{~Hz}$ didasarkan pada informasi pada sinyal ucapan berada pada frekuensi $0-4000 \mathrm{~Hz}$. Sehingga proses yang dilakukan cukup menggunakan frekuensi $8000 \mathrm{~Hz}$. Pre-processing atau pengolahan awal dilakukan untuk menghilangkan komponen frekuensi dc (frekuensi nol) yang terdapat didalam sinyal suara. Oleh sebab itu maka preprocessing dilakukan dengan filter pre-emphasis untuk mereduksi frekuensi DC dengan menggunakan High Pass Filter (HPF) seperti ditunjukkan pada gambar 4.
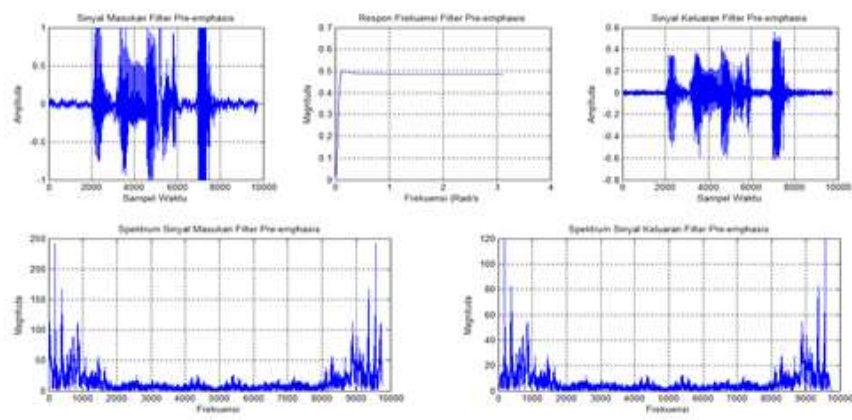

Gambar 5. Sinyal Masukan sebelum dan sesudah pre-processing

Gambar 5 (tengah) menunjukkan bahwa respon frekuensi dari filter yang digunakan adalah filter pelolos frekuensi tinggi dan meredam frekuensi DC (nol).

Proses dekomposisi Wavelet dilakukan untuk mengekstraksi informasi yang ada didalam sinyal suara, dengan membagi atau memecah sinyal tersebut ke dalam band-band frekuensi.

Sinyal suara terdekomposisi digambarkan oleh gambar 5 yang menunjukkan pada dekomposisi level=2, sinyal media dibagi kedalam 2 band frekuensi, yaitu band frekuensi rendah (komponen aproksimasi) dan band frekuensi tinggi (komponen detail).
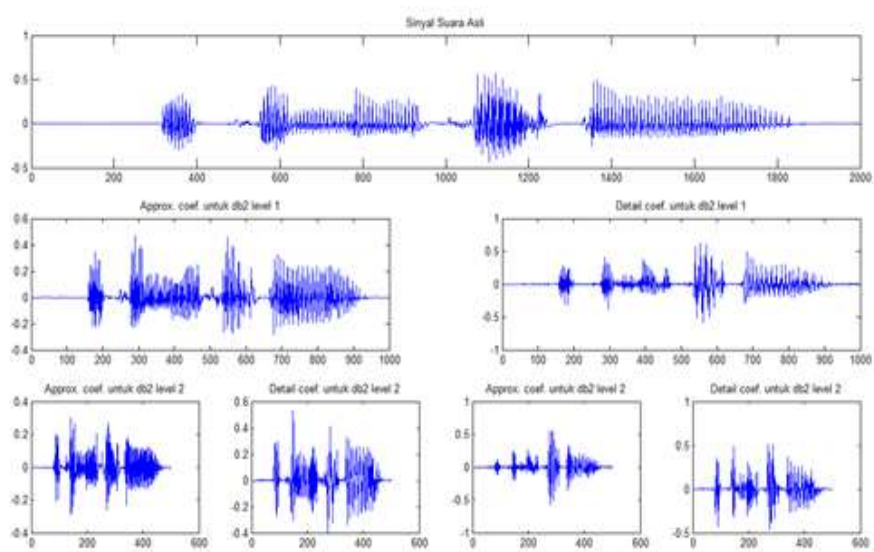

Gambar 6. Hasil dekomposisi sinyal suara level 2

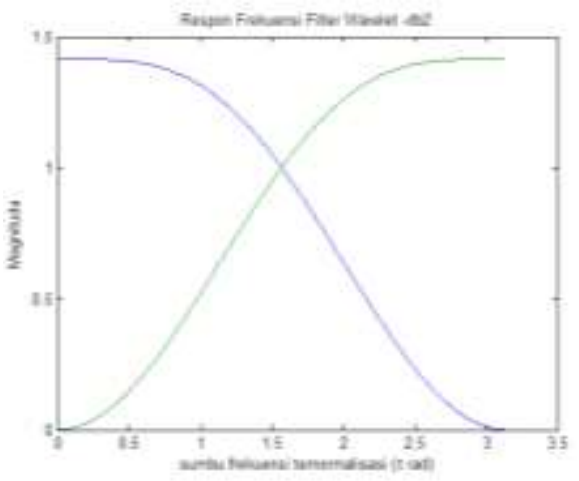

(a). Daubechies

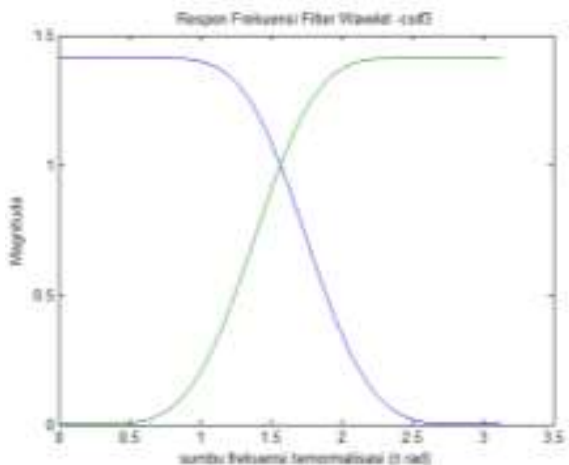

(b). Coiflet

Gambar 7. Respon frekuensi filter wavelet (LPF=biru), dan (HPF=hijau)

Gambar 7 (a) merupakan respon frekuensi tipe wavelet daubechies, dan gambar 7 (b) merupakan respon frekuensi tipe wavelet coiflet. Respon frekuensi yang berbeda akan memberikan hasil pengenalan yang berbeda pula.

\subsection{Pengujian Variabel Level Dekomposisi}

Dari data pada tabel 5 tersebut menunjukkan bahwa semakin besar level dekomposisi menyebabkan tingkat pengenalan semakin tinggi. Hal ini disebabkan karena semakin besar level dekomposisi semakin banyak jumlah informasi (Nilai Entropi) yang dapat digunakan untuk membedakan antara suara pembicara yang satu dengan yang lainnya.

Tabel 1. Tabel Pengaruh Level dekomposisi terhadap tingkat pengenalan

\begin{tabular}{cccc}
\hline $\begin{array}{c}\text { Jenis } \\
\text { Wavelet }\end{array}$ & $\begin{array}{c}\text { Level } \\
\text { Dekomposisi }\end{array}$ & $\begin{array}{c}\text { Running } \\
\text { time } \text { (detik) }\end{array}$ & $\begin{array}{c}\text { Tingkat } \\
\text { Pengenalan } \\
(\%)\end{array}$ \\
\hline $\mathrm{db} 1$ & 1 & 0,998 & 14,55 \\
\hline $\mathrm{db} 1$ & 2 & 2,046 & 51,82 \\
\hline $\mathrm{db} 1$ & 3 & 3,232 & 82,73 \\
\hline $\mathrm{db} 1$ & 4 & 4,814 & 98,18 \\
\hline $\mathrm{db} 1$ & 5 & 6,832 & 100,00 \\
\hline
\end{tabular}

Tabel 1 diatas juga menunjukkan bahwa semakin besar level dekomposisi waktu yang digunakan untuk proses dari awal sampai akhir juga semakin besar. Hal ini disebabkan karena semakin besar level dekomposisi maka semakin banyak data (nilai entropi) yang harus diproses untuk 
pengenalan sehingga membutuhkan lebih banyak waktu proses.

\subsection{Pengujian Variabel Jenis Filter Wavelet}

Transformasi Wavelet mempunyai banyak turunan yang dikembangkan karena banyaknya kelebihan dari transformasi wavelet. Tabel 2 menunjukkan bahwa untuk level dekomposisi yang sama yaitu 3 misalnya, tipe wavelet coiflet memberikan tingkat pengenalan paling tinggi (60\%), sedangkan symlet $(59,09 \%)$ dan daubechies $(57,27 \%)$ atau pada level dekomposisi $=4$, coiflet dengan tingkat pengenalan $(100 \%)$, symlet $(100 \%)$ dan daubechies $(99.09 \%)$. Sehingga secara umum tipe wavelet coiflet memberikan tingkat pengenalan yang paling tinggi dibandingkan 2 tipe wavelet yang lainnya.

Tabel 2. Pengaruh Jenis Filter Wavelet terhadap tingkat pengenalan

\begin{tabular}{cccc}
\hline $\begin{array}{c}\text { Jenis } \\
\text { Wavelet }\end{array}$ & $\begin{array}{c}\text { Order } \\
\text { Filter }\end{array}$ & $\begin{array}{c}\text { Level } \\
\text { Dekomposisi }\end{array}$ & $\begin{array}{c}\text { Tingkat } \\
\text { Pengenalan } \\
(\%)\end{array}$ \\
\hline db1 & 1 & 3 & 82,73 \\
\hline sym1 & 1 & 3 & 82,73 \\
\hline coif1 & 1 & 3 & 88,18 \\
\hline db2 & 2 & 3 & 83,64 \\
\hline sym2 & 2 & 3 & 83,64 \\
\hline coif2 & 2 & 3 & 90,00 \\
\hline db3 & 3 & 3 & 88,18 \\
\hline sym3 & 3 & 3 & 87,27 \\
\hline coif3 & 3 & 3 & 90,91 \\
\hline
\end{tabular}

\subsection{Pengujian Variabel Komponen Frekuensi}

Pengujian terhadap parameter frekuensi didasarkan bahwa informasi suara dominan (lebih banyak) berada di frekuensi rendah, sehingga pada frekuensi rendah rata-rata informasi (Entropinya) mirip, sehingga menyebabkan tingkat pengenalannya hanya 77,27\% jika proses pengenalan hanya menggunakan komponen frekuensi rendah (komponen aproksimasi) pada tabel 3. Sedangkan jika menggunakan komponen frekuensi tinggi (komponen detail) tingkat pengenalannya lebih tinggi yaitu $(87,27 \%)$. Ketika kedua komponen frekuensi digunakan (komponen aproksimasi+ komponen detail) didapatkan tingkat pengenalan $100 \%$.

Tabel 3. Pengaruh komponen frekuensi terhadap tingkat pengenalan

\begin{tabular}{|c|c|c|c|}
\hline $\begin{array}{c}\text { Nilai Entropy } \\
\text { dihitung dari } \\
\text { Bagian }\end{array}$ & Deskripsi & Variabel & $\begin{array}{c}\text { Tingkat } \\
\text { Pengenal- } \\
\text { an (\%) }\end{array}$ \\
\hline Aproksimasi & $\begin{array}{l}\text { Hanya } \\
\text { Frekuensi } \\
\text { Rendah }\end{array}$ & $\mathrm{EcA}$ & 77,27 \\
\hline Detail & $\begin{array}{l}\text { Hanya } \\
\text { Frekuensi } \\
\text { Tinggi }\end{array}$ & $\mathrm{EcD}$ & 87,27 \\
\hline $\begin{array}{l}\text { Aproksimasi } \\
+ \text { Detail }\end{array}$ & $\begin{array}{l}\text { Frekuensi } \\
\text { Rendah \& } \\
\text { Frekuensi } \\
\text { Tinggi }\end{array}$ & $\mathrm{EcA}+\mathrm{EcD}$ & 100,00 \\
\hline
\end{tabular}

\subsection{Pengujian Variabel Order Filter Wavelet}

Proses pengenalan dalam sistem ini juga diuji dengan parameter order filter wavelet untuk melihat pengaruhnya terhadap tingkat pengenalan.

Tabel 4. Pengaruh Order Filter Wavelet terhadap tingkat pengenalan

\begin{tabular}{ccc}
\hline $\begin{array}{c}\text { Jenis } \\
\text { Wavelet }\end{array}$ & $\begin{array}{c}\text { Level } \\
\text { Dekomposisi }\end{array}$ & $\begin{array}{c}\text { Tingkat } \\
\text { Pengenalan (\%) }\end{array}$ \\
\hline db2 & 1 & 18,18 \\
\hline sym2 & 1 & 16,36 \\
\hline coif2 & 1 & 25,45 \\
\hline db2 & 2 & 57,27 \\
\hline sym2 & 2 & 59,09 \\
\hline coif2 & 2 & 60,00 \\
\hline db2 & 3 & 83,64 \\
\hline sym2 & 3 & 83,64 \\
\hline coif2 & 3 & 90,00 \\
\hline db2 & 4 & 99,09 \\
\hline sym2 & 4 & 100,00 \\
\hline coif2 & 4 & 100,00 \\
\hline
\end{tabular}

Tabel 4 menunjukkan bahwa tingkat pengenalan berbeda untuk order filter yang berbeda.

\subsection{Pengujian Variabel Running time}

Pengujian sistem terhadap waktu yang diperlukan untuk proses identifikasi sampai dengan proses pengenalan dapat ditunjukkan pada tabel 5. Dan tabel 5 menunjukkan bahwa semakin besar level dekomposisi maka semakin besar pula waktu yang dibutuhkan untuk proses pengenalan.

Tabel 5. Running time untuk variasi level dekomposisi

\begin{tabular}{ccc}
\hline $\begin{array}{c}\text { Level } \\
\text { Dekomposisi }\end{array}$ & $\begin{array}{c}\text { Running time } \\
\text { (detik) }\end{array}$ & $\begin{array}{c}\text { Tingkat } \\
\text { Pengenalan (\%) }\end{array}$ \\
\hline 1 & 0,998 & 14,55 \\
\hline 2 & 2,046 & 51,82 \\
\hline 3 & 3,232 & 82,73 \\
\hline 4 & 4,814 & 98,18 \\
\hline 5 & 6,832 & 100,00 \\
\hline
\end{tabular}

Running time sangat dipengaruhi oleh spesifikasi komputer atau laptop yang digunakan untuk pengujian. Berikut adalah spesifikasi komputer yang digunakan :

1 Intel Pentium CPU P6300 @ 2,27GHz \& 2,26GHz, RAM 2 GB

2 Sistem Operasi Windows 8.1. Enterprise

3 Matlab R2010a

\subsection{FAR (False Acceptance Rate) dan FRR (False Rejection Rate)}

Pengujian terhadap kehandalan sistem pengenalan suara dapat dilakukan dengan menghitug nilai FAR (False Acceptance Rate) dan FRR (False Rejection Rate), sesuai dengan rumus berikut :

$F A R=\frac{\text { Pengujian user diluar database yang salah diterima }}{\text { jumlah user diluar database }} \times 100 \%$ 
$F R R=\frac{\text { Pengujian user didalam database yang salah ditolak }}{\text { jumlah user didalam database }} \times 100 \%$

Tabel 6. Pengujian FAR dan FRR terhadap sistem

\begin{tabular}{cccc}
\hline $\begin{array}{c}\text { Jenis } \\
\text { Wavelet }\end{array}$ & $\begin{array}{c}\text { Level } \\
\text { Dekomposisi }\end{array}$ & $\begin{array}{c}\text { FAR } \\
(\%)\end{array}$ & FRR (\%) \\
\hline $\mathrm{db} 2$ & 1 & $100 \%$ & 81,82 \\
\hline sym2 & 1 & $100 \%$ & 83,64 \\
\hline $\mathrm{coif2}$ & 1 & $100 \%$ & 74,55 \\
\hline $\mathrm{db2}$ & 2 & $83 \%$ & 42,73 \\
\hline sym2 & 2 & $83 \%$ & 40,91 \\
\hline coif2 & 2 & $67 \%$ & 40,00 \\
\hline $\mathrm{db} 2$ & 3 & $33 \%$ & 16,36 \\
\hline sym2 & 3 & $33 \%$ & 16,36 \\
\hline coif2 & 3 & $33 \%$ & 10,00 \\
\hline $\mathrm{db} 2$ & 4 & $0 \%$ & 0,91 \\
\hline sym2 & 4 & $17 \%$ & 0,00 \\
\hline coif2 & 4 & $0 \%$ & 0,00 \\
\hline $6 \mathrm{~m}$
\end{tabular}

Tabel 6 menunjukkan bahwa tingkat kesalahan sistem menerima pengguna di luar database (data pengguna yang diregistrasikan untuk dikenali) atau FAR adalah 0\% (yang berarti semua orang di luar database yang diujikan ditolak sistem) untuk Jenis wavelet daubechies order $2(\mathrm{db} 2)$ dan coiflet order 2 (coif2) dan dengan level dekomposisi 4. Dan sebaliknya pengujian dengan FRR atau kesalahan sistem menolak pengguna yang terdaftar di dalam database adalah $0 \%$ (yang berarti semua pengguna di dalam database diterima oleh sistem) untuk jenis wavelet symlet order 2 (sym2) dan coiflet order 2 (coif2) dan dengan level dekomposisi 4. Dan tabel 6 di atas menunjukkan semakin besar level dekomposisi, maka sistem semakin handal yang ditunjukkan dengan semakin kecilnya nilai FAR maupun FRR.

\section{KeSIMPULAN}

Berdasarkan hasil penelitian tersebut, maka dapat disimpulkan sebagai berikut :

1. Nilai thereshold filter wavelet identifikasi personel 57,72\%, False Rejection Rate (FRR) 40\% dan Running time 1,97 detik.

2. Nilai theresehold identifikasi personel $100 \%$, False Rejection Rate (FRR) 0\% dan Running time 5,43 detik didapatkan pada level dekomposisi 5 pada wavelet $\mathrm{db} 1$.

3. Identifikasi tipe wavelet dari yang terbaik adalah coiflet, symlet dan daubechies karena coif 2 level 2 memberikan identifikasi $60,00 \%$, FRR $40,00 \%$ dan Running time 1,97 detik.

\section{UCAPAN TERIMA KASIH}

Terima kasih kepada Kemenristek Dikti, BATAN dan PRSG BATAN melalui program INSINAS Flagship atas ijin penelitian serta dukungan dana. Terima kasih juga untuk Dr. Djoko Hari Nugroho atas bimbingannya.

\section{Daftar Pustaka}

[1] A. Tandyo And A. Widyatmoko, "Speaker Identification Menggunakan Transformasi Wavelet Diskrit Dan Jaringan Saraf Tiruan Back-Propagation Metode Tinjauan Pustaka," Pp. 1-7.

[2] W. Kurniawan, "Identifikasi Speech Recognition Manusia Dengan Menggunakan Average Energy Dan Silent Ratio Sebagai Feature Extraction Suara Pada Komputer," Biospecies, Vol. 9, No. 1, Pp. 1-6, 2016.

[3] Sutarno, C. Wajah, F. I. Komputer, And U. Sriwijaya, "Analisis Perbandingan Transformasi Wavelet," $J$. Generic, Vol. 5, No. 2, Pp. 15-21, 2010.

[4] S. Hidayat, H. R. P. Negara, And D. T. Kumoro, "Penentuan Fungsi Basis Wavelet Terbaik Untuk Sinyal Suara," Sntt Fgdt, Vol. 3, No. November, Pp. 247-252, 2017.

[5] Yohanes, Thiang, And S. Chandra, "Aplikasi Sistem Neuro-Fuzzy Untuk Pengenalan Kata," Tek. Elektro, Vol. 2, No. 2, Pp. 73-77, 2002.

[6] E. L. Utari, "Pengolahan Sinyal Kardiografi Dengan Menggunakan Alihragam Gelombang Singkat," Proc. Univ. Respati Yogyakarta, Pp. 90-96, 2014.

[7] M. M. Hidayat, "Pendahuluan Penggunaan," No. C, Pp. 233-240, 2014.

[8] C. E. Bire And B. Cahyono, "Denoising Pada Citra Menggunakan Transformasi Wavelet," Semin. Nas. Teknol. Inf. Dan Komun. Terap., Vol. 2012, No. Semantik, Pp. 487-493, 2012.

[9] B. Fatkhurrozi, M. A. Muslim, And D. R. Santoso, "Penggunaan Artificial Neuro Network System Dalam Penentuan Aktivitas Gunung Merapi," Vol. 6, No. 2, Pp. 113-118, 2012.

[10] B. Robi'in, “Analisis Dekomposisi Wavelet Pada Pengenalan Pola Lurik Dengan Metode Learning Vector Quantization," Ilk. J. Ilm., Vol. 9, Pp. 153-160, 2017. 